\title{
Pengaruh Return On Equity dan Debt Equity Ratio Terhadap Price Earning Ratio Pada Sektor Telekomunikasi Yang Terdaftar di BEI
}

\author{
Received: \\ 19 April 2021 \\ Revision \\ received: \\ 20 April 2021 \\ Accepted: \\ 23 April 2021
}

\author{
Kasir* dan Kartika \\ Program Studi Akuntansi, Sekolah Tinggi Ilmu Ekonomi Indonesia Membangun, Indonesia
}

\begin{abstract}
:
The purpose of this study was to determine the effect of ROE and DER on PER in telecommunications sector companies listed on the Indonesia Stock Exchange. The data used are secondary data. The regression model used is Multiple Regression Analysis. The results of this study by t test show that both Return On Equity and Debt to Equity Ratio have an effect on Price Earning Ratio. For the F test (simultaneous) states that the Return On Equity and Debt to Equity Ratio simultaneously affect the Price Earning Ratio. Based on the test results, the coefficient of determination shows that the Return On Equity and Debt to Equity Ratio have a simultaneous effect of $81.4 \%$ on the Price Earnings Ratio. The remaining $19.6 \%$ is influenced by other factors not included in this study, such as company size, sales growth.
\end{abstract}

Keywords: return on assets, debt to equity ratio, price earnings ratio

\begin{abstract}
Abstrak:
Tujuan penelitian ini untuk mengetahui pengaruh Return on Assets dan Debt to Equity Ratio terhadap Price Earnings Ratio pada perusahaan sektor telekomunikasi yang terdaftar di Bursa Efek Indonesia. Data yang digunakan adalah data sekunder. Model regresi yang dipergunakan Analisa Regresi Berganda. Hasil penelitian ini secara uji t menunjukan baik Return on Equity maupun Debt to Equity Ratio berpengaruh terhadap Price Earning Ratio. Untuk uji F (simultan) menyatakan bahwa Return on Equity maupun Debt to Equity Ratio secara simultan berpengaruh terhadap Price Earning Ratio. Berdasarkan hasil pengujian koefisien determinasi menunjukkan Return on Equity dan Debt to Equity Ratio memberikan pengaruh secara simultan sebesar 81,4\% terhadap Price Earnings Ratio. Sisanya 19,6\% dipengaruhi oleh faktor lain yang tidak di masukan dalam penelitian ini, seperti ukuran perusahaan, pertumbuhan penjualan.
\end{abstract}

Kata kunci: return on assets, debt to equity ratio, price earnings ratio

\section{Pendahuluan}

Investasi adalah aktivitas penempatan dana yang dimiliki pada aset investasi dengan harapan memperoleh suatu keuntungan. Tingkat pendapatan yang diharapkan (rate of return) dan risiko yang dihadapi merupakan dua hal penting yang harus diperhatikan oleh para investor dalam melakukan investasi. Sebelum melakukan investasi baik pemerintah maupun pihak swasta diharapkan untuk menganalisis terlebih dahulu kelayakan dari investasi tersebut. Semakin tinggi nilai Perusahaan, kemakmuran pemegang saham akan semakin meningkat. Nilai Perusahaan sangat penting karena 
mencerminkan kinerja perusahaan yang dapat mempengaruhi persepsi investor terhadap perusahaan (Dewi dan Wirajaya, 2013). Hubungan nilai perusahaan dengan kinerja keuangan mencerminkan prestasi keuangan yang dicapai oleh perusahaan yang tertuang pada laporan keuangan perusahaan. Kinerja keuangan dapat dinilai dengan melakukan analisis laporan keuangan dengan alat analisis berupa rasio keuangan yang akan memudahkan investor dalam pengambilan keputusan menanamkan modalnya pada suatu perusahaan. Price Earnings Ratio (PER) adalah perbandingan antara harga saham dengan laba bersih perusahaan, dimana harga saham sebuah emiten dibandingkan dengan laba bersih yang dihasilkan oleh emiten tersebut dalam setahun. Karena yang menjadi fokusnya adalah laba bersih yang dihasilkan perusahaan, maka dengan mengetahui Price Earnings Ratio sebuah emiten, bisa diketahui apakah harga sebuah saham tergolong wajar atau tidak. Oleh karena itu, Price Earnings Ratio ini sangat menarik perhatian para Investor dalam pendekatan untuk mengestimasi saham, maka menentukan faktor -faktor apakah yang mempengaruhi Price Earnings Ratio dengan mengetahui seberapa jauh faktor-faktor tersebut mempengaruhi Price Earnings Ratio adalah sangat penting (Mulyani dan Pitaloka, 2017).

PER sangat mudah untuk dihitung dan dipahami oleh investor. Dengan mengetahui harga di pasar dan laba bersih per saham, maka investor bisa menghitung berapa PER saham tersebut. Namun perlu dipahami, karena investasi di saham lebih banyak terkait dengan ekspektasi maka laba bersih yang dipakai dalam perhitungan biasanya laba bersih proyeksi untuk tahun berjalan. Dengan begitu bisa dipahami jika emiten berhasil membukukan laba besar, maka sahamnya akan diburu investor karena proyeksi laba untuk tahun berjalan kemungkinan besar akan naik. Besaran PER akan berubah-ubah mengikuti perubahan harga di pasar dan proyeksi laba bersih perseroan. Jika harga naik, proyeksi laba tetap, praktis Price Earning Ratio akan naik. Sebaliknya jika proyeksi laba naik, harga di pasar tidak bergerak maka Price Earning Ratio akan turun. Price Earning Ratio menunjukkan kepada investor kapan kira-kira harga sebuah saham akan balik modal. Penurunan harga saham dapat menjadi penyebab rendahnya nilai price earning ratio, selain itu rendahnya nilai price earning ratio juga dapat disebabkan oleh peningkatan laba bersih perusahaan. Saham akan semakin murah untuk di beli ketika nilai price earning ratio menunjukkan nilai yang kecil, saham yang murah akan membuat para investor tertarik untuk memperoleh saham dimana akan berdampak pada kinerja saham yang semakin membaik bagi perusahaan (Prasetyorini, 2013).

Debt to Equity Ratio merupakan salah satu faktor yang dapat mempengaruhi Nilai Perusahaan. Debt to Equity Ratio digunakan untuk mengukur perbandingan antara utang dengan modal sendiri. Debt to Equity Ratio menggambarkan risiko perusahaan menghadapi kebangkrutan. Debt to Equity Ratio yang semakin rendah mencerminkan semakin tinggi modal suatu perusahaan yang berasal dari modal sendiri. Debt to Equity Ratio yang tinggi menunjukkan tingginya ketergantungan permodalan perusahaan terhadap pihak luar, sehingga beban perusahaan juga semakin berat. Jika suatu perusahaan menanggung beban utang yang tinggi, yaitu melebihi modal sendiri yang dimiliki, maka harga saham perusahaan akan menurun (Ratih. et al, 2013).

Selain itu, faktor yang mempengaruhi nilai perusahaan adalah Return on Equity yang digunakan untuk mengukur banyaknya keuntungan yang akan diperoleh pemilik modal atas investasi yang telah dilakukan. Semakin besar Return on Equity, kinerja perusahaan semakin baik. Return on Equity menunjukkan keuntungan yang akan dinikmati oleh pemilik saham. Pertumbuhan Return on Equity menunjukkan prospek perusahaan yang semakin baik karena berarti adanya potensi peningkatan keuntungan yang diperoleh perusahaan. Hal ini ditangkap oleh para investor sebagai sinyal positif dari perusahaan sehingga akan meningkatkan kepercayaan para investor (Hermuningsih, 2013). Berdasarkan permasalahan diatas maka yang menjadi tujuan dari penelitian ini adalah untuk mengetahui pengaruh return on assets dan debt to equity ratio terhadap price earning ratio.

\section{Kajian Literatur}

Kinerja keuangan menurut Fahmi (2018) merupakan suatu analisis yang dilakukan guna mengetahui sejauh mana perusahaan sudah melaksanakan aturan yang sudah ditetapkan terkait dengan penggunaan keuangan secara tepat dan benar. Menurut Kariyoto (2017) kinerja keuangan adalah hasil aktivitas operasi perusahaan yang disajikan dalam bentuk angka-angka keuangan. Hasil aktivitas perusahaan periode sekarang harus dikomparasikan dengan (1) financial performance periode masa lalu, (2) 
anggaran neraca dan rugi keuntungan, dan (3) rata-rata financial performance perusahaan sejenis. Hasil perbandingan itu menunjukkan selisih yang menguntungkan atau merugikan, kemudian selisih itu dicari penyebabnya.

\section{Price Earning Ratio}

Menurut Brigham dan Daves (2015) price earning ratio merupakan perbandingan antara harga saham perusahaan dengan earning per share dalam saham. Price earning ratio adalah fungsi dari perubahan kemampuan laba yang diharapkan di masa yang akan datang. Semakin besar Price earning ratio, maka semakin besar pula kemungkinan perusahaan untuk tumbuh sehingga dapat meningkatkan nilai perusahaan. Pengukuran dalam menentukan Price earning ratio adalah dengan membandingkan harga pasar per lembar saham dengan laba per lembar saham.

\section{Price Earning Ratio = Harga saham per lembar saham /Laba per lembar saham}

\section{Return On Equity}

Menurut Kasmir (2019) return on equity atau rentabilitas modal sendiri adalah rasio untuk mengukur laba bersih sesudah pajak dengan modal sendiri. Return on Equity menunjukkan efisiensi penggunaan modal sendiri. Pengukuran untuk Return On Equity adalah dengan membandingkan laba setelah pajak dibagi dengan jumlah ekuitas.

\section{Return On Equity = (Earning After Tax / Total Equity $) x$ 100\%}

\section{Debt to Equity Ratio}

Debt to Equity Ratio menurut Fahmi (2018) adalah ukuran yang dipakai dalam menganalisis laporan keuangan untuk memperlihatkan besarnya jaminan yang tersedia untuk kreditor. Pengukuran untuk perhitungan Debt to Equity Ratio dapat menggunakan rumus rasio merupakan rasio yang digunakan untuk menilai utang dengan ekuitas.

\section{Debt Equity Ratio = Total Liabilites / Total Equity}

\section{Hubungan Return On Equity, Debt to Equity Ratio ke Price Earning Ratio}

Perusahaan dalam meningkatkan kinerjanya agar memperhatikan perkembangan Return On Equity dan Debt to Equity Ratio nya sehingga dapat meningkatkan Price Earning Ratio perusahaan (Sudaryani \& Sahroni, 2016).

H1 : Terdapat pengaruh Return On Equity terhadap Price Earning Ratio

H2 : Terdapat pengaruh Debt to Equity Ratio terhadap Price Earning Ratio

H3 : Terdapat pengaruh Return On Equity dan Debt to Equity Ratio terhadap Price Earning Ratio secara simultan

\section{Metode Penelitian}

Penelitian ini menggunakan metode deskriptif dan verifikatif. Penelitian deskriptif adalah penelitian yang bertujuan untuk menggambarkan atau melakukan keadaan objek atau subjek penelitian pada saat sekarang berdasarkan fakta-fakta yang tampak atau sebagaimana adanya. Sedangkan verifikatif menunjukkan penelitian mencari pengaruh antara variabel bebas terhadap variabel terikat. Dan data yang diambil adalah berupa data sekunder terdiri dari Price Earing Ratio, Return On Equity dan Debt Equity Ratio. Metode pengambilan data dengan menggunakan purposes sampling, yang diambil melalui www.idx.co.id dari tahun 2012 - 2019 di sektor telekomunikasi dengan sampel sebanyak 5 perusahaan dari populasi sebanyak 6 perusahaan.

\section{Model Penelitian}

Koefisien atau parameter untuk masing-masing variabel bebas akan dihasilkan melalui estimasi model ekonometrika yang dibentuk. Model ekonometrika dan penduga parameter dalam penelitian ini adalah dengan menggunakan regresi berganda sebagai berikut 
Dimana:

$$
P E R=R O E+D E R+\varepsilon
$$

$\begin{array}{ll}\text { PER } & =\text { Price Earning Ratio } \\ \text { ROE } & =\text { Return On Equity } \\ \text { DER } & =\text { Debt Equity Ratio } \\ \varepsilon & =\text { Error term }\end{array}$

\section{Pengujian Asumsi Klasik}

Uji asumsi klasik yang digunakan dalam penelitian ini adalah Uji Normalitas, Uji Multikolinearitas, Uji Heteroskedastisitas dan Uji Autokorelasi.

\section{Hasil dan Pembahasan}

\section{Hasil Analisis Deskriptif}

Analisis deskriptif bertujuan untuk menggambarkan secara sistematis dan faktual tentang fakta-fakta yang ada. Analisis deskriptif digunakan untuk menjawab identifikasi masalah yaitu bagaimana perkembangan Retur On Equity, Debt to Equity Ratio dan Price Earning Ratio pada sektor telekomunikasi yang terdaftar di BEI periode 2012-2019.

\section{Tabel 1 Analisis Deskriptif}

\begin{tabular}{cc|c|c|c|c} 
& N & Minimum & Maximum & Mean & Std. Deviation \\
\hline ROE_X1 & 40 &, 05 & 262,59 & 29,2413 & 53,15278 \\
\hline DER_X2 & 40 & 64,92 & 452,66 & 205,7012 & 112,31368 \\
\hline PER_Y & 40 &, 47 & 93,44 & 30,8806 & 25,62513 \\
\hline Valid N (listwise) & 40 & & & & \\
\hline
\end{tabular}

Hasil analisis deskriptif variabel Return On Equity pada tabel di atas menunjukan bahwa nilai minimum Return On Equity sebesar 0,05 dan nilai maksimum Return On Equity sebesar 0262,59. Adapun rata-rata dari Return On Equity sebesar 29,24 dengan tingkat simpangan bakunya sebesar 53,15 .

Hasil analisis deskriptif variabel Debt to Equity Ratio pada tabel di atas menunjukan bahwa nilai minimum Debt to Equity Ratio sebesar 64,92 dan nilai maksimum Debt to Equity Ratio sebesar 452,66. Adapun rata-rata dari Debt to Equity Ratio sebesar 205,70 dengan tingkat simpangan bakunya sebesar 112,31 .

Hasil analisis deskriptif variabel Price Earning Ratio pada tabel di atas menunjukan bahwa nilai minimum Price Earning Ratio sebesar 0,47 dan nilai maksimum Price Earning Ratio sebesar 93,44 Adapun rata-rata dari Price Earning Ratio sebesar 30,88 dengan tingkat simpangan bakunya sebesar 25,63 .

\section{Hasil Uji Asumsi Klasik}

Sebelum dilakukan pengujian hipotesis menggunakan regresi linier berganda, ada beberapa uji asumsi klasik yang harus dipenuhi agar kesimpulan dari regresi tersebut tidak bias. Pengujian asumsi ini terdiri atas 4 pengujian, yakni Uji Normalitas, Uji Multikolinieritas, Uji Autokorelasi dan Uji Heteroskedastistias.

Berikut adalah hasil uji normalitas dengan grafik normal $P$-P of regression standardized residual. Dari hasil uji normalitas dengan pendekatan grafik normal $P-P$ of regression standardized residual menunjukan bahwa dari gambar di atas, titik-titik tersebar mengikuti garis diagonal, sehingga dapat disimpulkan bahwa data telah terdisribusi dengan normal.

Berdasarkan hasil tabel 2, semua variabel independen memiliki nilai Variance Influence Factor $<10$ dan nilai tolerance $>10 \%$ maka berdasarkan hasil semua variabel independent yang diteliti tidak memiliki multikolinearitas.

Berdasarkan hasil tabel 3, nilai signifikansi >0,05 maka tidak terjadi heteroskedastisitas. 


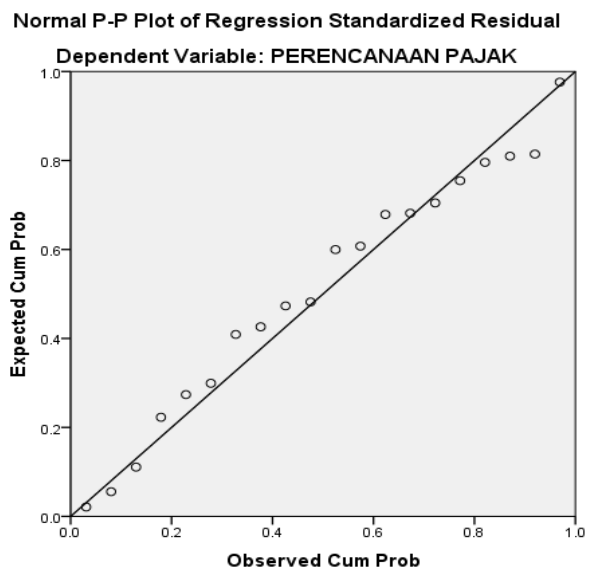

Gambar 1 Grafik Normalitas Data

Tabel 2 Uji Multikolonieritas

\begin{tabular}{|c|c|c|c|c|c|c|c|c|}
\hline \multirow{2}{*}{\multicolumn{2}{|c|}{ Model }} & \multicolumn{2}{|c|}{$\begin{array}{c}\text { Unstandardized } \\
\text { Coefficients }\end{array}$} & \multirow{2}{*}{$\begin{array}{c}\text { Standardized } \\
\text { Coefficients } \\
\text { Beta } \\
\end{array}$} & \multirow[t]{2}{*}{$\mathrm{t}$} & \multirow[t]{2}{*}{ Sig. } & \multicolumn{2}{|c|}{$\begin{array}{c}\text { Collinearity } \\
\text { Statistics } \\
\end{array}$} \\
\hline & & $\mathrm{B}$ & Std. Error & & & & Tolerance & VIF \\
\hline 1 & (Constant) & 110,314 & 12,546 & & 8,793 & ,000 & & \\
\hline & ROE_X1 & $-3,015$ & ,394 & $-1,250$ & $-7,655$ & ,000 & , 498 & 2,009 \\
\hline & DER_X2 &,- 204 & ,048 &,- 696 & $-4,263$ & ,001 & ,498 & 2,009 \\
\hline
\end{tabular}

a. Dependent Variable: PER_Y

Tabel 3 Uji Heterokedastistas

Unstandardized Coefficients Standardized Coefficients

\begin{tabular}{|c|c|c|c|c|c|c|}
\hline & Model & B & Std. Error & Beta & $\mathrm{t}$ & Sig. \\
\hline \multirow[t]{3}{*}{1} & (Constant) & $-1,024 \mathrm{E}-14$ & 12,546 & &, 000 & 1,000 \\
\hline & ROE_X1 & ,000 & ,394 &, 000 &, 000 & 1,000 \\
\hline & DER_X2 & ,000 & ,048 & ,000 & ,000 & 1,000 \\
\hline
\end{tabular}

a. Dependent Variable: Unstandardized Residual

Scatterplot

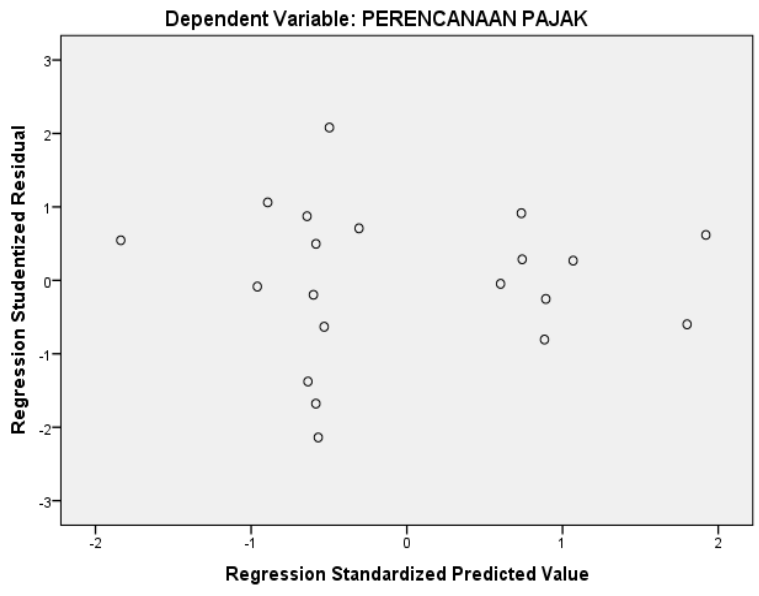

Gambar 2 Uji Heteroskedastisitas 
Dari gambar 2 terlihat bahwa titik-titik menyebar secara acak, tidak membentuk suatu pola. Serta titik-titik menyebar baik diatas maupun dibawah angka nol pada sumbu Y. Hal ini dapat disimpulkan bahwa tidak terjadi heterokedastisitas pada model regresi tersebut, sehingga model regresi layak dipakai untuk analisa berikutnya.

Berdasarkan tabel diatas bahwa Durbin Watson sebesar 1,941 dan nilai tersebut berada diantara 2 dan +2 atau $-2<$ DW $<+2$ maka disimpulkan bahwa model ini terdapat autokorelasi positif.

\begin{tabular}{ll|r|r|r|r}
\multicolumn{7}{c}{} & \multicolumn{9}{c}{ Tabel 4 Uji Autokorelasi } \\
Model & $\mathrm{R}$ & R Square & \multicolumn{1}{c}{$\begin{array}{c}\text { Adjusted R } \\
\text { Square }\end{array}$} & $\begin{array}{l}\text { Std. Error of } \\
\text { the Estimate }\end{array}$ & \multicolumn{1}{c}{$\begin{array}{c}\text { Durbin- } \\
\text { Watson }\end{array}$} \\
\hline 1 &, $902^{\mathrm{a}}$ &, 814 &, 788 & 11,62866 & 1,941 \\
\hline
\end{tabular}

a. Predictors: (Constant), DER_X2, ROE_X1

b. Dependent Variable: PER_Y

\section{Analisis Regresi Berganda}

Analisis ini digunakan untuk mengetahui pengaruh beberapa variabel independen $(\mathrm{X})$ terhadap variabel dependen $(\mathrm{Y})$. Model regresi berganda yang akan dibentuk adalah sebagai berikut:

$$
\mathrm{Y}=\alpha+\beta_{1} \mathrm{X}_{1}+\beta_{2} \mathrm{X}_{2}+\mathrm{e}
$$

$\begin{array}{ll}\text { Dimana: } & \\ \mathrm{Y} & =\text { Price Earning Ratio } \\ \alpha & =\text { Konstanta } \\ \beta_{1}, \beta_{2}, & =\text { Koefisien regresi } \\ \mathrm{X}_{1} & =\text { Return On Equity } \\ \mathrm{X}_{2} & =\text { Debt to Equity Ratio } \\ \mathrm{e} & =\text { Error }\end{array}$

Hasil perhitungan regresi linier berganda adalah sebagai berikut :

Tabel 5 Analisa Regresi Berganda

\begin{tabular}{|c|c|c|c|c|c|c|c|}
\hline \multirow[b]{2}{*}{ Model } & \multicolumn{2}{|c|}{$\begin{array}{l}\text { Unstandardized } \\
\text { Coefficients }\end{array}$} & \multirow{2}{*}{$\begin{array}{c}\text { Standardized } \\
\text { Coefficients } \\
\text { Beta } \\
\end{array}$} & \multirow[b]{2}{*}{$\mathrm{t}$} & \multirow[b]{2}{*}{ Sig. } & \multicolumn{2}{|c|}{$\begin{array}{l}\text { Collinearity } \\
\text { Statistics }\end{array}$} \\
\hline & $\mathrm{B}$ & Std. Error & & & & Tolerance & VIF \\
\hline 1 (Constant) & 110,314 & 12,546 & & 8,793 & 000 & & \\
\hline ROE_X1 & $-3,015$ & ,394 & $-1,250$ & $-7,655$ & ,000 & ,498 & 2,009 \\
\hline DER_X2 &,- 204 & ,048 &,- 696 & $-4,263$ & ,001 & ,498 & 2,009 \\
\hline
\end{tabular}

a. Dependent Variable: PER_Y

Dari output di atas diketahui nilai konstanta dan koefisien regresi sehingga dapat dibentuk persamaan regresi linier berganda sebagai berikut:

$$
\mathrm{Y}=\mathbf{1 1 0}, 314-3,015 \mathrm{X}_{1}-\mathbf{0 , 2 0 4 X _ { 2 }}
$$

Persamaan di atas dapat diartikan sebagai berikut:

$\alpha=110,314 \quad$ artinya jika variabel Return On Equity (X1), Debt to Equity Ratio (X2) bernilai nol (0), maka nilai variabel Price Earning Ratio (Y) diperoleh 110.

$\mathrm{B}_{1}=-12,777$ artinya setiap penambahan satu satuan variabel Return On Equity $\left(\mathrm{X}_{1}\right)$ dan variabel lainnya konstan, maka akan menurunkan nilai variabel Price Earning Ratio $(\mathrm{Y})$ sebesar - 3,015. Sebaliknya setiap penurunan satu satuan variabel Return On Equity $\left(\mathrm{X}_{1}\right)$ dan 
variabel lainnya konstan, maka akan menurunkan variabel Price Earning Ratio (Y) sebesar - 3,015.

$\mathrm{B}_{2}=0,013 \quad$ artinya setiap penambahan satu satuan variabel Debt to Equity Ratio $\left(\mathrm{X}_{2}\right)$ dan variabel lainnya konstan, maka akan meningkatkan nilai variabel Price Earning Ratio (Y) sebesar - 0,204. Sebaliknya setiap penurunan satu satuan variabel Debt to Equity Ratio $\left(\mathrm{X}_{2}\right)$ dan variabel lainnya konstan, maka akan menurunkan variabel Price Earning Ratio (Y) sebesar-0,204.

\section{Hasil Pengujian Koefisien Korelasi}

Perhitungan koefisien korelasi yang digunakan dalam penelitian ini adalah menggunakan korelasi Product Moment. Hasil perhitungan untuk koefisien korelasi adalah sebagai berikut:

Tabel 6 Uji Koefisien Korelasi

\begin{tabular}{llr|r|r} 
& & ROE_X1 & DER_X2 & PER_Y \\
\hline \multirow{2}{*}{ ROE_X1 } & Pearson Correlation & 1 &,$- 709^{* *}$ &,$- 757^{* *}$ \\
\cline { 2 - 5 } & Sig. (2-tailed) & &, 001 &, 000 \\
\cline { 2 - 5 } & $\mathrm{N}$ & 40 & 40 & 40 \\
\hline \multirow{2}{*}{ DER_X2 } & Pearson Correlation &,$- 709^{* * *}$ & 1 &,- 057 \\
\cline { 2 - 5 } & Sig. (2-tailed) &, 001 & &, 823 \\
\cline { 2 - 5 } & $\mathrm{N}$ & 40 & 40 & 40 \\
\hline \multirow{2}{*}{ PER_Y } & Pearson Correlation &,$- 757^{* *}$ &,- 057 & 1 \\
& Sig. (2-tailed) &, 000 &, 823 & \\
\cline { 2 - 5 } & $\mathrm{N}$ & 40 & 40 & 40 \\
\hline
\end{tabular}

Berdasarkan hasil perhitungan di atas, dapat diketahui bahwa besar korelasi antara Return On Equity (X1) terhadap Price Earning Ratio (Y) adalah sebesar -0,757. Hal tersebut menunjukan bahwa terdapat korelasi negatif yang sangat rendah antara Return On Equity (X1) terhadap Price Earning Ratio (Y). Besaran korelasi antara Debt to Equity Ratio (X2) terhadap Price Earning Ratio (Y) adalah sebesar -0,057. Hal tersebut menunjukkan bahwa terdapat korelasi positif yang rendah antara Debt to Equity Ratio (X2) terhadap Price Earning Ratio (Y).

\section{Hasil Analisis Koefisien Determinasi}

Dari hasil perhitungan koefisien korelasi di atas, dapat diketahui nilai koefisien determinasi sebagai berikut:

\begin{tabular}{lc|r|r|r|r} 
& \multicolumn{7}{c}{ Tabel 7 Analisis Koefisien Determinasi } & \\
Model & $\mathrm{R}$ & R Square & \multicolumn{1}{c}{$\begin{array}{c}\text { Sdjusted R } \\
\text { Square }\end{array}$} & $\begin{array}{c}\text { Std. Error of } \\
\text { the Estimate }\end{array}$ & \multicolumn{1}{c}{$\begin{array}{c}\text { Durbin- } \\
\text { Watson }\end{array}$} \\
\hline 1 &, $902^{\mathrm{a}}$ &, 814 &, 788 & 11,62866 & 1,941 \\
\hline
\end{tabular}

a. Predictors: (Constant), DER_X2, ROE_X1

b. Dependent Variable: PER_Y

Dengan demikian, maka diperoleh nilai koefisien determinasi sebesar $81,4 \%$ yang menunjukkan arti bahwa Return On Equity $\left(\mathrm{X}_{1}\right)$, Debt to Equity Ratio $\left(\mathrm{X}_{2}\right)$ memberikan pengaruh simultan (bersamasama) sebesar 81,4\% terhadap Price Earning Ratio (Y). Sedangkan sisanya sebesar 19,6\% dipengaruhi oleh faktor lain yang tidak di masukan dalam penelitian ini, seperti ukuran perusahaan, pertumbuhan penjualan. 


\section{Pengujian Hipotesis Parsial (Uji t)}

Uji hipotesis parsial (Uji t) digunakan untuk mengetahui besarnya pengaruh pajak tangguhan dan leverage terhadap perencanaan pajak secara terpisah. Hasil perhitungan pengujian parsial adalah sebagai berikut:

\begin{tabular}{|c|c|c|c|c|c|c|c|}
\hline \multirow[b]{3}{*}{ Model } & \multirow{2}{*}{\multicolumn{2}{|c|}{$\begin{array}{l}\text { Unstandardized } \\
\text { Coefficients }\end{array}$}} & \multicolumn{5}{|l|}{ Tabel 8 Uji t } \\
\hline & & & \multirow{2}{*}{$\begin{array}{l}\text { Standardized } \\
\text { Coefficients } \\
\text { Beta } \\
\end{array}$} & \multirow[b]{2}{*}{$\mathrm{t}$} & \multirow[b]{2}{*}{ Sig. } & \multicolumn{2}{|c|}{$\begin{array}{c}\text { Collinearity } \\
\text { Statistics }\end{array}$} \\
\hline & B & Std. Error & & & & Tolerance & VIF \\
\hline 1 (Constant) & 110,314 & 12,546 & & 8,793 &, 000 & & \\
\hline ROE_X1 & $-3,015$ & ,394 & $-1,250$ & $-7,655$ &, 000 & ,498 & 2,009 \\
\hline DER_X2 &,- 204 &, 048 &,- 696 & $-4,263$ & ,001 & ,498 & 2,009 \\
\hline
\end{tabular}

a. Dependent Variable: PER_Y

Berdasarkan perhitungan diatas maka :

a. Diperoleh nilai thitung untuk Return On Equity $\left(\mathrm{X}_{1}\right)$ sebesar 0,000 dan tabel 2,026. Dikarenakan nilai sig $<0,05$ lebih besar dari $t_{\text {tabel }}$ maka terdapat pengaruh variabel $\mathrm{X}$ terhadap variabel $\mathrm{Y}$. Artinya Return On Equity berpengaruh terhadap Price Earning Ratio.

b. Diperoleh nilai $t_{\text {hitung }}$ untuk Debt to Equity Ratio (X2) sebesar 0,001 dan $t_{\text {tabel }}$ 2,026. Dikarenakan nilai sig $<0,05$ lebih besar dari $t_{\text {tabel}}$, maka terdapat pengaruh variabel $\mathrm{X}$ terhadap variabel $\mathrm{Y}$ artinya Debt to Equity Ratio berpengaruh terhadap Price Earning Ratio.

\section{Pengujian Hipotesis Simultan (F)}

Uji hipotesis simultan (Uji F) digunakan untuk mengetahui besarnya pengaruh Return On Equity dan Debt to Equity Ratio terhadap Price Earning Ratio secara bersama-sama. Hasil perhitungan pengujian simulatan adalah sebagai berikut :

Tabel 9 Uji F

\begin{tabular}{llr|r|r|r|r} 
Model & & Sum of Squares & df & Mean Square & F & \multicolumn{1}{c}{ Sig. } \\
\hline \multirow{2}{*}{1} & Regression & 8290,639 & 2 & 4145,320 & 30,655 &, $000^{\mathrm{b}}$ \\
\cline { 2 - 7 } & Residual & 1893,162 & 14 & 135,226 & & \\
\cline { 2 - 7 } & Total & 10183,801 & 16 & & & \\
\hline
\end{tabular}

a. Dependent Variable: PER_Y

b. Predictors: (Constant), DER_X2, ROE_X1

Berdasarkan output di atas diketahui nilai signifikansi untuk pengaruh Return On Equity (X1) dan Debt to Equity Ratio (X2) secara simultan terhadap Price Earning Ratio (Y) adalah sebesar F hutung 30,655 $>$ F tabel 3,24 maka dapat diambil kesimpulan bahwa terdapat pengaruh Return On Equity dan Debt to Equity Ratio secara simultan terhadap Price Earning Ratio.

\section{Pengaruh Return On Equity terhadap Price Earning Ratio}

Hasil pengujian hipotesis secara parsial diperoleh return on equity berpengaruh terhadap price earning ratio. Artinya bahwa Return On Equity mencerminkan keefektifan perusahaan memperoleh laba bersih terhadap para pemilik saham. Naiknya nilai Return On Equity mencerminkan semakin banyak perusahaan menghasilkan laba, sehingga investor akan tertarik untuk menginvestasikan dananya sehingga mengakibatkan naiknya Price Earning Ratio. Hal ini sejalan dengan penelitian yang dilakukan oleh (Sudaryani \& Sahroni, 2016) yang menyatakan bahwa return on equity secara parsial berpengaruh terhadap price earning ratio. 


\section{Pengaruh Debt to Equity Ratio terhadap Price Earning Ratio}

Hasil pengujian hipotesis secara parsial diperoleh debt to equity ratio berpengaruh terhadap Price Earning Ratio. Artinya semakin rendah nilai debt to equity ratio maka semakin tinggi pula nilai Price Earning Ratio. Hal ini sejalan dengan penelitian yang dilakukan oleh (Sudaryani \& Sahroni, 2016) yang menyatakan bahwa debt to equity ratio yang secara parsial berpengaruh terhadap price earning ratio.

\section{Pengaruh Return On Equity dan Debt to Equity Ratio terhadap Price Earning Ratio}

Hasil pengujian hipotesis secara simultan diperoleh Return On Equity dan Debt to Equity Ratio secara bersama-sama berpengaruh terhadap price earning ratio. Dan berdasarkan hasil pengujian koefisien determinasi menunjukkan Return On Equity dan Debt to Equity Ratio memberikan pengaruh secara simultan (bersama-sama) sebesar $81,4 \%$ terhadap Price Earning Ratio. Sedangkan sisanya sebesar $19,6 \%$ dipengaruhi oleh faktor lain yang tidak di masukan dalam penelitian ini, seperti ukuran perusahaan, pertumbuhan penjualan.

\section{Kesimpulan}

Berdasarkan hasil penelitian dan pembahasan dapat disimpulkan bahwa baik Return on Equity maupun Debt to Equity Ratio secara parsial berpengaruh terhadap price earning ratio. Secara simultan Return on Equity maupun Debt to Equity Ratio berpengaruh terhadap price earning ratio sebesar 81,4\%. Sedangkan sisanya sebesar 19,6\% dipengaruhi oleh faktor lain yang tidak di masukan dalam penelitian ini, seperti ukuran perusahaan, pertumbuhan penjualan.

\section{Daftar Pustaka}

Abdurrahman, M. Agus Salim, Afi Rachmat Slamet. (2015). Pengaruh Dividend Per Share (DPS), Net Profit Margin (NPM) dan Return On Equity (ROE) Terhadap Harga Saham (Perusahaan Industri Manufaktur yang tercatat di Bursa Efek Indonesia Periode 2012-2015). E-Jurnal Riset Manajemen Universitas Islam Malang.

Brigham, Eugene F., dan Joel F. Houston. (2015). Dasar-Dasar Manajemen Keuangan Edisi 14. Jakarta: Salemba Empat.

Chasanah, Amalia Nur. (2018). Pengaruh Rasio Likuiditas, Profitabilitas, Struktur Modal Dan Ukuran Perusahaan Terhadap Nilai Perusahaan Pada Perusahaan Manufaktur yang Terdaftar di Bursa Efek Indonesia Tahun 2015-2017. Jurnal Penelitian Ekonomi dan Bismis Vol.3 No.1. Semarang.

Dorothea Ratih, Apriatni E.P dan Saryadi (2013). Pengaruh EPS, PER, DER, ROE terhadap harga saham pada sektor pertambangan yang terdaftar di BEI tahun 2010-2012 DIPONEGORO JOURNAL OF SOCIAL AND POLITIC Tahun 2013, Hal. 1-12

Dedeh Sri Sudaryanti, Nana Sahroni, 2016. PENGARUH RETURN ON EQUITY (ROE) DAN DEBT TO EQUITY RATIO (DER) TERHADAP PRICE EARNING RATIO (PER) Jurnal Ekonomi Manajemen Volume 2 Nomor 1 (Mei 2016) 40-47, http://jurnal.unsil.ac.id/index.php/jem, ISSN 2477-2275 (Print)

Dewi, Ayu Sri Mahatma dan Ary Wirajaya. (2013). Pengaruh Struktur Modal, Profitabilitas, dan Ukuran Perusahaan pada Nilai Perusahaan. E-Jurnal Akuntansi Universitas Udayana Vol.4 No.2. Bali.

Fahmi, Irham. (2018). Pengantar Manajemen Keuangan Teori dan Soal Jawab. Bandung: Alfabeta.

Kariyoto. (2017). Analisis Laporan Keuangan. Malang: Universitas Brawijaya Press.

Kasmir. (2019). Pengantar Manajemen Keuangan Edisi Kedua Cetakan ke-7. Jakarta: PT Rajagrafindo Persada.

Mulyani dan Pitaloka. (2017. Pengaruh Return on Equity, Earning per Share (EPS), dan Debt to Equity Ratio terhadap Price Earning Ratio (PER) Pada PT Indofood Sukses Makmur. Tbk Periode 2012-2014, Widyakala Volume 4 No. 1 Maret 2017 ISSN : 2337-7313

Prasetyorini, Bhekti Fitri. (2013). Pengaruh Ukuran Perusahaan, Leverage, Price Earning Ratio dan Profitabilitas terhadap Nilai Perusahaan. Jurnal Ilmu Manajemen, 1(1): 183-196

\section{*Email korespondensi: \\ kasirinaba@gmail.com}

